\title{
Evaluación clínica y radiográfica de la distracción alveolar
}

\author{
A clinical and radiographic evaluation of the alveolar distraction
}

Los autores en el presente artículo presentan los resultados de la técnica de distracción alveolar, comunican 15 casos de distracción alveolar de la zona anterior del maxilar superior, la ganancia media fue de 7,04 mm y tuvieron un alto número de complicaciones 53,33, si bien solo en 1 paciente existió una complicación mayor. La mayoría de las complicaciones son dehiscencias e infecciones y el caso de fracaso mayor consistió en la imposibilidad de activar el distractor, aunque no indican si fue debido a defectos del aparato o a un mal diseño del segmento de transporte y/o a una falta de comprobar la activación del distractor intraoperatoriamente. Recientemente Chiapasco en el año 2004, publica un estudio multicéntrico con 37 pacientes sometidos a distracción alveolar, 9,9 mm de ganancia ósea y 138 implantes colocados y cargados con un seguimiento medio postcarga de 9,9 meses y un éxito 4 años después del 94,2\%, tuvieron un bajo número de complicaciones, $13,5 \%$, referidas a problemas de dirección del vector y solo un fracaso por mal diseño de la pastilla de transporte.

En el artículo de evaluación clínica y radiológica de la distracción alveolar, se centran los autores en la evaluación radiológica de la ganancia ósea, pero echamos de menos un mejor análisis clínico de sus casos, cuántos implantes se colocaron y si éstos tuvieron éxito. El número de complicaciones que tuvieron es alto, si bien solo un caso representó un fracaso. La mayoría de los autores que publican sobre distracción centran más las complicaciones en las dificultades de dirigir el vector de distracción que en las infecciones locales, aunque es probable que no analicen un problema menor como es la dehiscencia de la sutura o cicatriz.

La distracción ósea es la producción de un callo óseo con capacidad osteogénica en un hueso al que se le ha realizado una osteotomía y sus extremos han sido sometidos a un proceso de tensión progresiva y mantenida. La distracción para que sea eficaz, debe ser gradual y progresiva sin interrumpir el aporte vascular. En la zona de distracción ocurren los mismos fenómenos básicos que en la curación de las fracturas, desde la fase inicial de callo fibroso a la fase final de remodelación ósea y producción de hueso maduro. Es preceptivo, de acuerdo con la Literatura, la estabilidad del callo, esto es, que el distractor no permita movilidad en el fragmento distraído.

La distracción alveolar tiene su indicación principal en el sector anterior maxilar y mandibular, donde consigue un alargamiento simultáneo de las partes blandas y los resultados son muy predecibles.

En el sector posterior maxilar, donde no existen requerimientos estéticos tan altos, la técnica de elevación de seno e injertos puede ser en el momento actual aún más aconsejable, aunque los defen-
The authors of this article present the results of the alveolar distraction technique, reporting 15 cases of alveolar distraction of the anterior region of the upper maxilla. The mean gain was $7.04 \mathrm{~mm}$ and the number of complications was high at 53.33\%, although there was only a major complication in one patient. Most of the complications were due to dehiscence and infection and the case with the major failure consisted in it being impossible to activate the distractor, although we are not told if this was due to a defect of the device or to a badly designed transport segment and/or to a failure to check the activation of the distractor intraoperatively.

Recently, Chiapasco published in 2004 a multicenter study of 37 patients that underwent alveolar distraction. There was a $9.9 \mathrm{~mm}$ mean bone gain, 138 implants were placed and loaded with an average post-loading follow-up of 9.9 months and a success rate 4 years later of $94.2 \%$. The complication rate was low at $13.5 \%$, which was related to problems with the direction of the vector, and there was only one failure due to the faulty design of the transport disk.

In the article 'A clinical and radiographic evaluation of the distraction osteogenesis technique for the reconstruction of atrophic alveolar ridges in the anterior region of the upper maxilla.' the authors concentrate on evaluating bone gain radiologically, but we miss a better clinical analysis of these cases, with regards to how many implants were placed and if these were successful. The number of complications experienced was high, although there was only one failure. Most of the authors that publish articles on distraction center the complications more on the difficulties in directing the vector of distraction than on local infections, although they probably do not analyze lesser problems such as the dehiscence of sutures and scars.

Bone distraction is the production of a bone callus with osteogenic capacity in a bone in which an osteotomy has been carried out and its ends have been subjected to a process of progressive tension that is maintained. In order for the distraction to be effective, it has to be gradual and progressive and the vascular supply should not be interrupted. In the distraction area the same basic phenomena occur as in the healing of a fracture, from the initial fibrous callus phase to the final phase of bone remodeling and the production of mature bone. The stability of the callus is, according to the literature, mandatory. That is, the dis- 
sores de la distracción apuntan que esta técnica permite generar hueso desde abajo, retornando a una situación más fisiológica al disminuir el espacio protético, en muchos casos aumentado por la reabsorción ósea previa, mejorando así la relación corona-implante y en casos concretos consiguiendo una sonrisa más estética.

\section{J.I. Salmerón Escobar \\ Servicio de Cirugía Oral y Maxilofacial Hospital Universitario Gregorio Marañón. Madrid. España}

\section{Bibliografía}

1. Bilbao Alonso A. Regeneración del proceso alveolar: Distracción ósea. Rev Esp Cir Oral Maxilofac. 2002;24:298-303.

2. Chiapasco M, Consolo U, Bianchi A, Ronchi P. Alveolar distraction Osteogenesis for the correction of vertically Deficient Edentulous Ridges: A Multicenter Prospective Study on Humans. Int J Oral Maxillofac Imp/ 2004;3:399-407.

3. Hidding J, Lazar F, Zoller JE. Initial outcome of vertical distraction osteogenesis of the atrophic alveolar ridge. Mund Kiefer Gesichtschir 1999;3:79-83.

4. Hidding J, Zoller JE, Lazar F. Micro and macrodistraction of the jaw. A sure method of adding new bone. Mund Kiefer Gesichtschir 2000;4:432-7.

5. Jensen OT, Cockrell R, Kuhlke L, Reed Ch. Anterior Maxillary Distraction Osteogenesis: A Prospective 5-Year Clinical Study. En: Jensen O. Alveolar Distraction Osteogenesis. Quintessence Publishing Co. Chicago. 2002;p.p.95-118.

6. Salmerón JI, Calderón J. Distracción alveolar. En: Navarro C. Tratado de Cirugía Oral y Maxilofacial. Madrid. Aran Ediciones. 2004.

7. Salmerón JI, Riba F. Distracción alveolar. Gaceta Dental 2004;150:52-63.

8. Riba F, Del Amo A, Salmerón Jl, Cuesta M. Cirugía Preprotésica. En: Martín-Granizo R. Manual de Cirugía Oral y Maxilofacial. Madrid. Editorial ENE. 2004;p.p.34365.

9. García A, Somoza M, Gándara P, López J. Minor complications Arising in alveolar distraccion osteogenesis. J Oral Maxillofac Surg 2002;60:496-501. tractor should not allow any movement in the distracted fragment.

Alveolar distraction is indicated principally for the anterior portion of the maxilla and mandible, where simultaneous lengthening of soft tissue is achieved with very predictable results.

In the posterior portion of the maxilla, where the aesthetic requirements are not so high, the grafting and sinus elevation techniques may be more advisable at the present time, although those defending distraction indicate that this technique allows bone to be generated from below, returning to a more physiological state as the prosthetic space is reduced, in many cases increased by previous bone resorption, while the crown-implant relationship is improved and in specific cases a more aesthetic smile is achieved. 